\title{
Comparative study of zinc addition effect on thermal properties of silicate and phosphate glasses
}

\author{
J. Sułowska ${ }^{1} \cdot$ I. Wacławska ${ }^{1} \cdot$ M. Szumera ${ }^{1}$
}

Received: 30 April 2015/ Accepted: 14 September 2015/Published online: 3 October 2015

(C) The Author(s) 2015. This article is published with open access at Springerlink.com

\begin{abstract}
The aim of the study was an analysis of two groups of glasses from the $\mathrm{SiO}_{2}-\mathrm{P}_{2} \mathrm{O}_{5}-\mathrm{K}_{2} \mathrm{O}-\mathrm{CaO}-\mathrm{MgO}$ system with various content of network formers in the form of $\mathrm{P}_{2} \mathrm{O}_{5}$ and $\mathrm{SiO}_{2}$, modified by the addition of $\mathrm{ZnO}$. Their effect on glass-forming ability, glass transition effect, crystallization process and the kind of crystallizing phases was examined using DSC and XRD methods. It was observed that in both matrixes, the addition of $\mathrm{ZnO}$ decreases the glass transition temperature $\left(T_{\mathrm{g}}\right)$. The lower $T_{\mathrm{g}}$ values observed in the phosphate matrix glasses and the accompanying higher values of the changes in molar heat capacity $\left(\Delta c_{\mathrm{p}}\right)$ in contrast to the silicate matrix glasses may be considered an indicator of the degree of the reconstruction of their amorphous structure, which facilitates the process of their crystallization. It was found that the crystallizing products of the silicate matrix glasses were silicates and phosphates whose structure contained zinc. In the phosphate matrix glasses, it was observed that zinc inhibited the crystallization of silicate phases.
\end{abstract}

Keywords Silicate-phosphate glasses $\cdot \mathrm{ZnO} \cdot$ Glass transition $\cdot$ Thermal stability $\cdot$ Crystallization

\section{Introduction}

Phosphate and silicate glasses containing zinc have been studied intensively, because many of them have been found useful for special applications.

\section{J. Sułowska}

sulowska@agh.edu.pl

1 Department of Ceramics and Refractories, Faculty of Materials Science and Ceramics, AGH University of Science and Technology, A. Mickiewicza 30, 30-059 Kraków, Poland
Zinc phosphate glasses have been developed for use as LED light sources $[1,2]$ and as substrates for optical waveguides written by f-sec lasers [3-6]. Zinc phosphate glasses also tend to have greater coefficients of thermal expansion with low processing temperatures, which makes them useful as sealing glasses [7, 8]. Because zinc is a trace element that plays an important role in bone formation and mineralization $[9,10]$, zinc-containing glasses and glass ceramics have been developed for bone engineering applications [11-13]. Zinc has also been cited as a useful antibacterial agent in glass-ionomer-based cements [14] and ceramic coatings [15]. Thus, the addition of zinc to various materials and their use in bone tissue engineering may have important implications for appropriate integration into implant sites with minimal bone infection risk, a complication often associated with the repair of skeletal defects.

It is a well-known fact that the ability to absorb components that function as modifiers is much higher in the phosphate matrix glasses than in the silicate matrix glasses. The ability to take the amorphous form also depends on the kind of introduced modifiers [16, 17]. The works [18-20] show that it is possible to add up to $80 \mathrm{~mol} \%$ of $\mathrm{ZnO}$ into the structure of the glasses from the system $\mathrm{P}_{2} \mathrm{O}_{5}-\mathrm{ZnO}$. Examining the scope of forming silicate glasses modified with $\mathrm{ZnO}$, Kaur et al. [21] produced silicate glass with the composition $40 \mathrm{SiO}_{2}-30 \mathrm{BaO}-20 \mathrm{ZnO}-10 \mathrm{~B}_{2} \mathrm{O}_{3}\left(\mathrm{Al}_{2} \mathrm{O}_{3}\right)$, and Hurt and Philips [22] introduced $35 \mathrm{~mol} \% \mathrm{ZnO}$ into the structure of the glasses from the $\mathrm{Na}_{2} \mathrm{O}-\mathrm{ZnO}-\mathrm{SiO}_{2}$ system. The research done by Minser et al. [23] shows that it is possible to obtain fully amorphous glass from the $\mathrm{Na}_{2} \mathrm{O}-$ $\mathrm{ZnO}-\mathrm{SiO}_{2}$ system if it contains the addition of $\mathrm{ZnO}$ in the amount of up to $30 \%$ mol. The research on the glasses with the composition $(100-x) \mathrm{SiO}_{2}-7 \mathrm{CaO}-5 \mathrm{~K}_{2} \mathrm{O}-19 \mathrm{Na}_{2} \mathrm{O}-$ $x \mathrm{ZnO}$ done by Chen et al. [24] indicates that adding over $19 \mathrm{~mol} \%$ of $\mathrm{ZnO}$ causes their crystallization. 
There is little information in the literature about the possibility of introducing zinc into the structure of silicatephosphate glasses. Goel et al. [25] introduced the additive $\mathrm{ZnO}$ into the structure of glasses composed of $36.07 \mathrm{CaO}-$ $(19.24-x) \mathrm{MgO}-x \mathrm{ZnO}-5.61 \mathrm{P}_{2} \mathrm{O}_{5}-38.49 \mathrm{SiO}_{2}-0.59 \mathrm{CaF}_{2}$, where $x \leq 10 \mathrm{~mol} \%$, produced in the traditional melting process, and Aina et al. [26], employing the same method for the synthesis, obtained fully amorphous glass containing 20.2 mass $\% \mathrm{ZnO}$ and $37.3 \% \mathrm{SiO}_{2}, \quad 18.8 \% \mathrm{Na}_{2} \mathrm{O}$, $18.9 \% \mathrm{CaO}, 4.5 \% \mathrm{P}_{2} \mathrm{O}_{5}$ (mass\%). In the literature, there are also references on the ability to form silicate-phosphate glasses that contain $\mathrm{ZnO}$ and are precursors of glass-crystalline materials to which $\mathrm{P}_{2} \mathrm{O}_{5}$ was added as a nucleating agent. An example is the work of Demirkesen et al. [27] who obtained fully amorphous silicate glass with the composition $10 \mathrm{Li}_{2} \mathrm{O}-32 \mathrm{ZnO}-55 \mathrm{SiO}_{2}-3 \mathrm{P}_{2} \mathrm{O}_{5}$ (mass \%).

There is little information in the literature on the influence of the addition of $\mathrm{ZnO}$ on thermal properties of silicate and phosphate glasses, and even less on silicatephosphate glasses.

The authors [28] examined the transformation of the vitreous state of the glasses with the composition $50 \mathrm{P}_{2} \mathrm{O}_{5}$ $(40-x \mathrm{CaO})-10 \mathrm{Na}_{2} \mathrm{O}-x \mathrm{ZnO}$, where $x \leq 20 \mathrm{~mol} \%$. Their research shows that adding increased amounts of $\mathrm{ZnO}$ caused a linear decrease in the values of the transition temperature $\left(T_{\mathrm{g}}\right)$ of those glasses. According to the authors, it resulted from the formation of weaker $\mathrm{Zn}-\mathrm{O}-\mathrm{P}$ bonds that replace $\mathrm{Ca}-\mathrm{O}-\mathrm{P}$ bonds and from the decrease in the crosslink density of those glasses. Thermal test carried out on the glasses with the composition $(\mathrm{MnO})_{\mathrm{x}} \cdot\left(\mathrm{P}_{2} \mathrm{O}_{5}\right)_{40} \cdot(\mathrm{ZnO})_{60-\mathrm{x}}$ where $x=0-20 \%$ mol. [29] showed that a gradual decrease in $\mathrm{ZnO}$ content in the structure of the abovementioned glasses caused a slight decrease in the $T_{\mathrm{g}}$, yet all $T_{\mathrm{g}}$ values were close to $415{ }^{\circ} \mathrm{C}$ so zinc phosphate matrix is poorly affected by the substitution of $\mathrm{ZnO}$ with $\mathrm{MnO}$ up to $20 \mathrm{~mol} \%$. On the other hand, thermal tests of glasses with the compositions $(50-x) \mathrm{ZnO} \cdot x \mathrm{MgO} \cdot 50 \mathrm{P}_{2} \mathrm{O}_{5}(0 \geq x \geq 50)$ and $(60-y) \mathrm{ZnO} \cdot \mathrm{yMgO} \cdot 40 \mathrm{P}_{2} \mathrm{O}_{5}(0 \geq x \geq 60)$ [30] indicate that a gradual decrease in the content of $\mathrm{ZnO}$ and the simultaneous increase in the content of $\mathrm{MgO}$ cause an increase in the $T_{\mathrm{g}}$ value from $\sim 450$ to $\sim 600{ }^{\circ} \mathrm{C}$. Testing glasses from the system $\mathrm{Li}_{2} \mathrm{O}-\mathrm{ZnO}-\mathrm{Al}_{2} \mathrm{O}_{3}-\mathrm{SiO}_{2}$, Demirkesen and Maytalman [31] observed an increase in the $T_{\mathrm{g}}$ value of the glasses parallel to the decrease in the content of $\mathrm{ZnO}$ with the simultaneous increase in the amount of the introduced $\mathrm{Al}_{2} \mathrm{O}_{3}$. This behaviour can be attributed to strengthening of the bonds within the glass network upon replacement of $\mathrm{ZnO}$ by $\mathrm{Al}_{2} \mathrm{O}_{3}$. The research done by the authors [32] indicates that the increased addition of $\mathrm{ZnO}$ into the structure of bioactive silicatephosphate glass from the $\mathrm{SiO}_{2}-\mathrm{CaO}-\mathrm{Na}_{2} \mathrm{O}-\mathrm{P}_{2} \mathrm{O}_{5}-\mathrm{ZnO}$ system at the expense of the simultaneous decrease in the content of $\mathrm{CaO}$ and $\mathrm{Na}_{2} \mathrm{O}$ does not cause major changes in the $T_{\mathrm{g}}$ value or in the crystallization temperature of those glasses.

The object of those studies was silicate-phosphate glasses from the $\mathrm{SiO}_{2}-\mathrm{P}_{2} \mathrm{O}_{5}-\mathrm{K}_{2} \mathrm{O}-\mathrm{CaO}-\mathrm{MgO}$ system which can act as slow-dissolving fertilizers providing plant macroelements ( $\mathrm{P}, \mathrm{K}, \mathrm{Ca}$, and $\mathrm{Mg}$ ) [33], as well as zinc acting as microelement. Zinc plays an active role in many life processes of plants, including the metabolism of carbohydrates, proteins, and phosphorus compounds. It also influences the synthesis of auxins, regulates the formation of ribosomes, and affects the permeability of cell membranes [34].

The presented work includes the results of comparative studies on the influence of the addition of zinc ions introduced at the expense of the decrease in the amount of calcium and magnesium on the glass-forming ability and the thermal characteristics of the glasses from the abovementioned system, with different content of such network formers as $\mathrm{SiO}_{2}$ and $\mathrm{P}_{2} \mathrm{O}_{5}$.

\section{Experimental}

Two groups of glasses from $\mathrm{SiO}_{2}-\mathrm{P}_{2} \mathrm{O}_{5}-\mathrm{K}_{2} \mathrm{O}-\mathrm{CaO}-\mathrm{MgO}$ system differing in glass network formers content (the $\mathrm{Si}$ group of glasses and the $\mathrm{P}$ group of glasses) modified by $\mathrm{ZnO}$ addition were prepared. In each group of glasses, constant quantities of $\mathrm{SiO}_{2}, \mathrm{P}_{2} \mathrm{O}_{5}$, and $\mathrm{K}_{2} \mathrm{O}$ were kept and increasing amount of $\mathrm{ZnO}$ was introduced at the cost of decreasing amount of $\mathrm{MgO}$ and $\mathrm{CaO}$, with the constant $\mathrm{MgO} / \mathrm{CaO}$ ratio. The glasses were produced by melting the mixture of raw materials, i.e. $\mathrm{SiO}_{2},\left(\mathrm{NH}_{4}\right)_{2} \mathrm{HPO}_{4}, \mathrm{~K}_{2} \mathrm{CO}_{3}, \mathrm{MgO}, \mathrm{CaCO}_{3}$, and $\mathrm{ZnO}$ in platinum crucibles at $1100{ }^{\circ} \mathrm{C}$ (the phosphate glasses) and at $1450{ }^{\circ} \mathrm{C}$ (the silicate glasses). The obtained glasses were ground to 0.1 - to 0.3 -mm grain size.

The chemical composition of the synthesized glasses was determined by the X-ray fluorescence spectrometry (XRF) method, using the ARL Advant'XP spectrometer.

The X-ray diffraction method was used to confirm the amorphous state of the samples using X'Pert Pro Diffractometer (Phillips) with a step of $0.008^{\circ}$ and collecting time $45 \mathrm{~s}$.

Thermal stability of the obtained glasses was determined by DSC measurements conducted on STA 449 F3 Jupiter 7 (Netzsch) operating in the heat flux DSC mode. The temperature and heat calibrations of the instrument were performed using the melting temperatures and melting enthalpies of high-purity aluminium, tin, zinc, silver, and gold. The samples $(\sim 40 \mathrm{mg})$ were heated in platinum crucibles at $10{ }^{\circ} \mathrm{C} \mathrm{min}^{-1}$ in dry nitrogen atmosphere up to $1100{ }^{\circ} \mathrm{C}$. The glass transformation temperature $T_{\mathrm{g}}$ determined as the midpoint of the $c_{\mathrm{p}}$ changes in the glass 
transformation region and changes in specific heat $\left(\Delta c_{\mathrm{p}}\right)$ accompanying the glass transformation was determined by applying the Netzsch Proteus Thermal Analysis Program (version 5.0.0.). The ability of glasses to crystallize was evaluated from the values of the thermal stability parameter of glasses $(\Delta T)$ determined as:

$\Delta T=T_{\text {onset }}-T_{\mathrm{g}}$

where $T_{\text {onset }}$ is the onset temperature of the first crystallization stage and $T_{\mathrm{g}}$ is the glass transition temperature of the given sample.

The samples containing the particle size of $0.1-0.3 \mathrm{~mm}$ were isothermally heated for $5 \mathrm{~h}$ at the crystallization temperatures that were inferred from DSC measurements. The temperature stability was better than $\pm 5{ }^{\circ} \mathrm{C}$. The resulted crystalline phases were detected and identified by XRD method.

\section{Results and discussion}

Homogeneous, transparent glasses were obtained from all compositions studied. The nominal chemical composition of the glasses determined by the X-ray fluorescence spectrometry (XRF) method is presented in Table 1.

The chemical analysis of the chosen glasses showed a satisfying conformance of their assumed and real chemical compositions. Therefore, it was assumed that the chemical compositions of all melted glasses fulfil the assumptions.

\section{Glass-forming ability}

The XRD tests (Fig. 1) showed that all obtained glasses are fully amorphous in the concentration range in question. Hence, the solubility of $\mathrm{ZnO}$ in the structure of the glasses from the $\mathrm{SiO}_{2}-\mathrm{P}_{2} \mathrm{O}_{5}-\mathrm{K}_{2} \mathrm{O}-\mathrm{CaO}-\mathrm{MgO}$ system in the examined concentration range does not depend on the content of network formers $\left(\mathrm{SiO}_{2}, \mathrm{P}_{2} \mathrm{O}_{5}\right)$.

\section{Glass transition}

During heating and cooling, vitreous substances exhibit glass transition effect which is induced by relaxation of stresses being the consequence of a disordered arrangement of the atoms forming the glass structure. The relaxation of stresses in the glass structure taking place at transition temperature $\left(T_{\mathrm{g}}\right)$ is related to a change in such properties as heat capacity, linear and volume expansion coefficients, and viscosity. Parameters characterizing the glass transition effect depend on the nature and the number of components forming the glassy structure.

The DSC tests showed that the increase in the addition of $\mathrm{ZnO}$ into the structure of both glass groups causes a gradual decrease in their $T_{\mathrm{g}}$ value (Fig. $2 \mathrm{a}, \mathrm{b}$ ). The $T_{\mathrm{g}}$ values are higher by about $150{ }^{\circ} \mathrm{C}$ in the silicate matrix glasses (41Si) (Fig. 3) than in the phosphate matrix glasses (41P).

Regardless of the vitreous matrix, the decrease in the $T_{\mathrm{g}}$ value was accompanied by a decrease in the $\Delta c_{\mathrm{p}}$ value, which was better visible in the glasses with the higher content of $\mathrm{SiO}_{2}$ (Table 2).

The changes in the glass transition temperature values $\left(T_{\mathrm{g}}\right)$ could be explained based on the nature of chemical bonds in the structure of the glasses. The ionicity $\left(i_{\mathrm{G}}\right)$ value of the bonds of the component atoms with oxygen according to Görlich's scale [35] was applied as a parameter characterizing the strength of the bonds. It increases with decreasing iconicity. Another parameter is the localization of the bonding electron " $L$ " $=\overline{Z_{\text {eff }}}=\sqrt{Z_{\text {eff1 }} \cdot Z_{\text {eff2 }}}$ [35]. Its value increases with the covalence of the bonds

Table 1 Nominal chemical composition of glasses and determined by the X-ray fluorescence spectrometry (XRF) (in brackets) in mol\%

\begin{tabular}{|c|c|c|c|c|c|c|c|}
\hline Group of glasses & Glass name & $\mathrm{SiO}_{2}$ & $\mathrm{P}_{2} \mathrm{O}_{5}$ & $\mathrm{~K}_{2} \mathrm{O}$ & $\mathrm{CaO}$ & $\mathrm{MgO}$ & $\mathrm{ZnO}$ \\
\hline \multirow[t]{6}{*}{ The Si group } & $0 \mathrm{Zn} 41 \mathrm{Si}$ & 41 & 6 & 6 & 19 & 28 & \\
\hline & $2 \mathrm{Zn} 41 \mathrm{Si}$ & $41(37.6)$ & $6(5.7)$ & $6(7.5)$ & $18(19.1)$ & $27(27.8)$ & $2(2.3)$ \\
\hline & $4 \mathrm{Zn} 41 \mathrm{Si}$ & $41(37.9)$ & $6(5.6)$ & $6(7.5)$ & $17(18.0)$ & $26(26.7)$ & $4(4.3)$ \\
\hline & 8Zn41Si & $41(38.0)$ & $6(6.1)$ & $6(7.3)$ & $16(17.2)$ & $23(23.1)$ & $8(8.3)$ \\
\hline & $15 \mathrm{Zn} 41 \mathrm{Si}$ & 41 & 6 & 6 & 13 & 19 & 15 \\
\hline & $30 \mathrm{Zn} 41 \mathrm{Si}$ & 41 & 6 & 6 & 7 & 10 & 30 \\
\hline \multirow[t]{6}{*}{ The P group } & 0Zn41P & $6(6.3)$ & $41(41.2)$ & $6(6.2)$ & 19 (19.6) & $28(26.7)$ & \\
\hline & $2 \mathrm{Zn} 41 \mathrm{P}$ & 6 & 41 & 6 & 18 & 27 & 2 \\
\hline & $4 Z n 41 P$ & $6(5.8)$ & $41(41.5)$ & $6(6.1)$ & $17(17.4)$ & $26(25.1)$ & $4(4.1)$ \\
\hline & $8 \mathrm{Zn} 41 \mathrm{P}$ & 6 & 41 & 6 & 16 & 23 & 8 \\
\hline & $15 Z n 41 P$ & $6(5.3)$ & $41(40.6)$ & $6(5.8)$ & $13(13.8)$ & $19(18.2)$ & $15(16.3)$ \\
\hline & $30 \mathrm{Zn} 41 \mathrm{P}$ & 6 & 41 & 6 & 7 & 10 & 30 \\
\hline
\end{tabular}




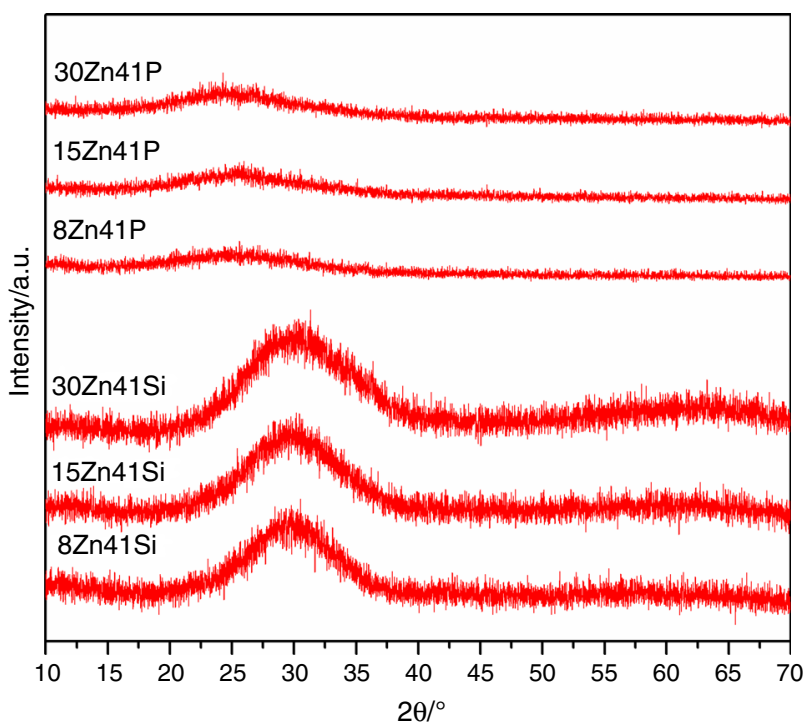

Fig. 1 XRD patterns of the glasses

with oxygen, and this parameter has been accepted as a measure of the rigidity of the bonds. The more covalent character of $\mathrm{Zn}-\mathrm{O}$ bonds $\left(i_{\mathrm{G}}=0.639, L=1.914\right)$ replacing the more ionic bonds such as $\mathrm{Ca}-\mathrm{O}$ bonds $\left(i_{\mathrm{G}}=0.707\right.$, $L=1.725)$ and $\mathrm{Mg}-\mathrm{O}$ bonds $\left(i_{\mathrm{G}}=0.670, L=1.830\right)$ made the glass structure more rigid the consequence of which was increased stress in the glass. Its relaxation required less energy and hence lower $T_{\mathrm{g}}$ value with the increase in the content of $\mathrm{ZnO}$ in the structure of both types of glasses. Simultaneously, due to the more covalent character of $\mathrm{P}-\mathrm{O}$ bonds $\left(i_{\mathrm{G}}=0.314, L=2.640\right)$ compared to $\mathrm{Si}-\mathrm{O}$ bonds $\left(i_{\mathrm{G}}=0.428, L=2.410\right)$, the phosphate

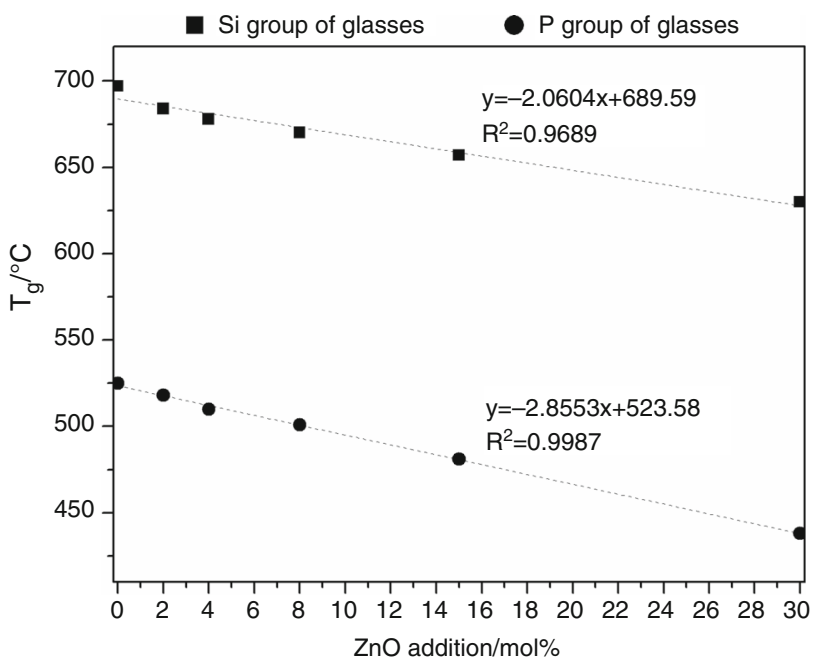

Fig. 3 Glass transition temperature values $\left(T_{\mathrm{g}}\right)$ versus molar concentration of $\mathrm{ZnO}$ in the structure of the studied glasses

matrix glasses show lower $T_{\mathrm{g}}$ temperature values than silicate matrix glasses. The relaxation of more stresses in the structure of phosphate matrix glasses (41P) than in the structure of silicate matrix glasses (41Si) was accompanied by a slightly higher change in the $\Delta c_{\mathrm{p}}$ parameter accompanying the transition of the vitreous state.

\section{Crystallization}

The thermal tests carried out on the analysed glasses allowed to determine the influence of the increasing addition of $\mathrm{ZnO}$ and the network formers on their
Fig. 2 DSC curves of the a $\mathrm{Si}$ group and $\mathbf{b} \mathbf{P}$ group of glasses
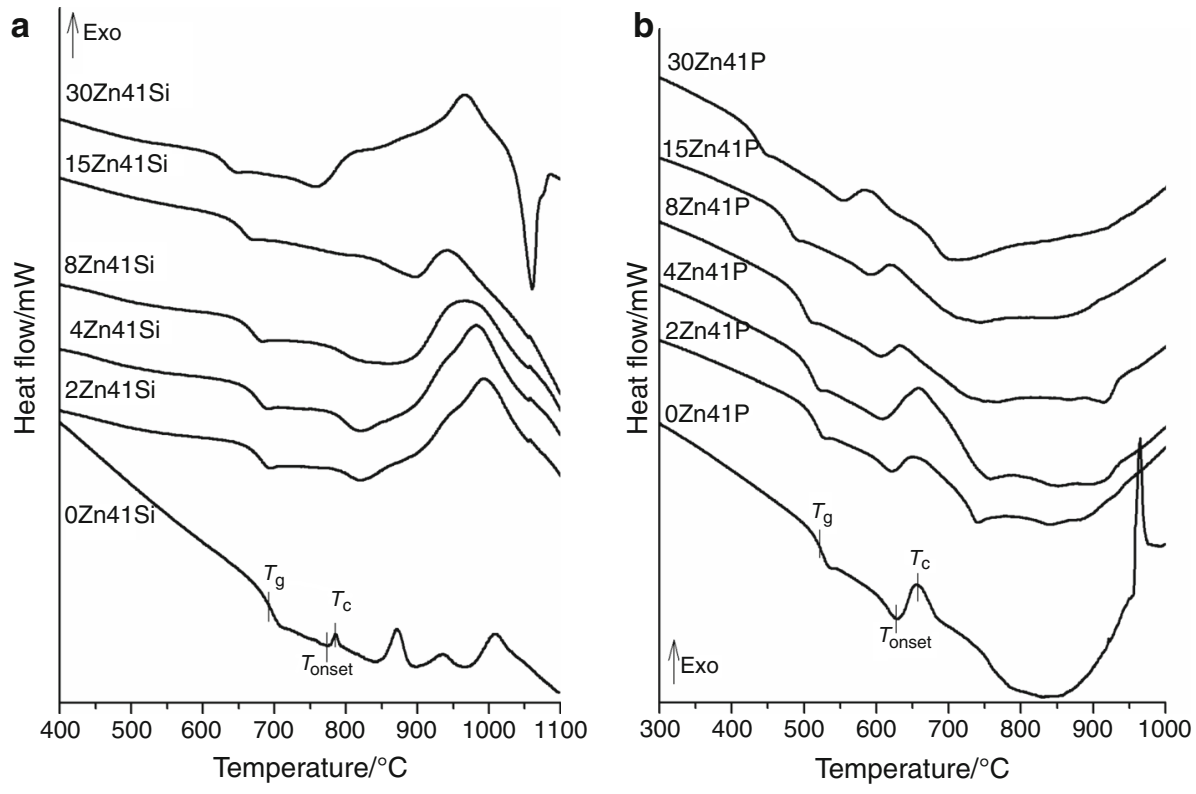
Table 2 Thermal characteristic of the transition of vitreous state and the thermal durability of the glasses from the $\mathrm{SiO}_{2}-\mathrm{P}_{2} \mathrm{O}_{5}-\mathrm{K}_{2} \mathrm{O}-\mathrm{CaO}-\mathrm{MgO}$ system modified with the addition of $\mathrm{ZnO}$ at the expense of the simultaneous decrease in the content of $\mathrm{CaO}$ and $\mathrm{MgO}$

\begin{tabular}{|c|c|c|c|c|c|c|c|}
\hline Glass name & $T_{\mathrm{g}} /{ }^{\circ} \mathrm{C}$ & $\Delta c_{\mathrm{p}} / \mathrm{J} \mathrm{g}^{-1} \mathrm{~K}^{-1}$ & $\Delta T /{ }^{\circ} \mathrm{C}$ & Glass name & $T_{\mathrm{g}} /{ }^{\circ} \mathrm{C}$ & $\Delta c_{\mathrm{p}} / \mathrm{J} \mathrm{g}^{-1} \mathrm{~K}^{-1}$ & $\Delta T /{ }^{\circ} \mathrm{C}$ \\
\hline 0Zn41Si & 697 & 0.31 & 81 & $0 \mathrm{Zn} 41 \mathrm{P}$ & 525 & 0.27 & 112 \\
\hline 2Zn41Si & 684 & 0.24 & 138 & $2 \mathrm{Zn} 41 \mathrm{P}$ & 518 & 0.29 & 109 \\
\hline $4 \mathrm{Zn} 41 \mathrm{Si}$ & 678 & 0.26 & 144 & $4 Z n 41 P$ & 510 & 0.29 & 109 \\
\hline 8Zn41Si & 670 & 0.25 & 193 & $8 \mathrm{Zn} 41 \mathrm{P}$ & 501 & 0.33 & 109 \\
\hline 15Zn41Si & 657 & 0.19 & 242 & $15 Z n 41 P$ & 481 & 0.26 & 119 \\
\hline 30Zn41Si & 630 & 0.17 & 131 & 30Zn41P & 438 & 0.23 & 120 \\
\hline
\end{tabular}

crystallization ability determined based on the $\Delta T$ parameter (Table 2).

It was observed that the crystallization ability of the phosphate matrix glasses (41P) modified by $\mathrm{ZnO}$ addition is higher than crystallization ability of the silicate matrix glasses $(41 \mathrm{Si})$. The crystallization ability of $41 \mathrm{Si}$ glasses decreases with increasing amount of $\mathrm{ZnO}$ up to $15 \mathrm{~mol} \%$ addition, while the addition of $30 \mathrm{~mol} \%$ of $\mathrm{ZnO}$ causes the rapid reduction in $\Delta T$ parameter value.

In reference to the already conducted analysis of the atomic reactions in the structures of the examined glasses, based on the characteristic of the nature of the formed chemical bonds, it should be noted that lower $T_{\mathrm{g}}$ values accompanied by higher $\Delta c_{\mathrm{p}}$ values that are related to the reduction in structural stresses (breaking chemical bonds) are equivalent to the higher level of reconstruction of the amorphous structure of the glass which takes place before the crystallization process. Hence, the phosphate matrix glasses have lower thermal stability and higher crystallization ability compared to the silicate matrix glasses. The glass transition effect expressed with such parameters as $T_{\mathrm{g}}$ and $\Delta c_{\mathrm{p}}$ may be treated as an indicator of the level of the reconstruction of the disordered structure of glasses towards their crystallization [36].

The DSC curves of glasses (Fig. 2a, b) show that the crystallization of the base glasses $(0 \mathrm{Zn})$ from the two examined groups of glass was a multi-stage process with four stages ( $\mathrm{Si}$ group glass) and two stages (P group glass). The introduction of the increasing amount of $\mathrm{ZnO}$ to the composition of the studied glasses changed the character of exothermal effects whose number was reduced and they were overlapping.

The analysis of the crystallization products of the silicate matrix glasses showed that the main crystallizing phases found in the base glass $(0 \mathrm{Zn} 41 \mathrm{Si})$ are orthophosphate of $\mathrm{Ca}_{9} \mathrm{MgK}\left(\mathrm{PO}_{4}\right)_{7}$ type and disilicate of $\mathrm{CaMgSi}_{2} \mathrm{O}_{6}$ type (Table 3).
It was found that the increasing amount of zinc ions in the structure of those glasses facilitates the formation of $\mathrm{Ca}_{9} \mathrm{ZnK}\left(\mathrm{PO}_{4}\right)_{7}$ orthophosphate during their crystallization (Fig. 4). It was also observed that the increase in the content of $\mathrm{ZnO}$ in the structure of the studied glasses caused a diversification of crystallization products in the form of silicates. Apart from $\mathrm{CaMgSi}_{2} \mathrm{O}_{6}$-type silicate (diopside), the crystallization products included $\mathrm{Mg}_{2} \mathrm{SiO}_{4^{-}}$ type orthosilicate (forsterite) and an orthosilicate containing zinc $\mathrm{Zn}_{2} \mathrm{SiO}_{4}$ (willemite).

The XRD study of the base glass with phosphate matrix (0Zn41P) (Table 3) showed that the crystallization products of the glass are polyphosphate compounds composed of $\mathrm{KMg}\left(\mathrm{PO}_{3}\right)_{3}$ and $\mathrm{CaMgP}_{2} \mathrm{O}_{7}$. The type of the formed phosphate networks conforms to the structural classification of phosphate glasses based on the $O / P$ ratio [37]. In the group of the tested phosphate matrix glasses, the $O / P$ ratio was 3.3 , which conforms to the structures typical of metaand pyrophosphates.

The increase in the amount of $\mathrm{ZnO}$ up to $15 \mathrm{~mol} \%$ apart from the above-mentioned types of phosphates results in the formation of pyrophosphates containing zinc, such as $\mathrm{K}_{2} \mathrm{ZnP}_{2} \mathrm{O}_{7}$ (Fig. 5). For the glass $30 \mathrm{Zn} 41 \mathrm{P}$, there is no evidence of crystallization of $\mathrm{KMg}\left(\mathrm{PO}_{3}\right)_{3}$ and $\mathrm{CaMgP}_{2} \mathrm{O}_{7}$ compounds, but apart from the formation of $\mathrm{K}_{2} \mathrm{ZnP}_{2} \mathrm{O}_{7}$, the appearance of magnesium-rich metaphosphate of $\mathrm{Mg}_{2} \mathrm{P}_{4}$ $\mathrm{O}_{12}$ type was detected.

It should also be noted that the introduction of increasing amounts of $\mathrm{ZnO}$ into the structure of phosphate matrix glasses inhibits the crystallization of silicate phases.

It was found that the succession of the appearance of the crystallization products in the form of phosphates and silicates in the analysed glasses (Table 4) resulted from the value of Gibbs free enthalpy in the formation of phosphates and silicates from oxides $(\Delta G)$ which determines the probability of their formation (Table 4 ). 
Table 3 X-ray characteristics of crystallization process of analysed glasses

\begin{tabular}{|c|c|c|}
\hline Glass name & $T_{\mathrm{c}} /{ }^{\circ} \mathrm{C}$ & Crystalline phase (ICSD code) \\
\hline \multirow[t]{6}{*}{ 0Zn41Si } & 786 & $\mathrm{Ca}_{9} \mathrm{MgK}\left(\mathrm{PO}_{4}\right)_{7}(88-0798)$ \\
\hline & 872 & $\mathrm{Ca}_{9} \mathrm{MgK}\left(\mathrm{PO}_{4}\right)_{7}(88-0798)$ \\
\hline & 935 & $\mathrm{Ca}_{9} \mathrm{MgK}\left(\mathrm{PO}_{4}\right)_{7}(88-0798)$ \\
\hline & & $\mathrm{CaMgSi}_{2} \mathrm{O}_{6}(03-0522)$ \\
\hline & 1010 & $\mathrm{CaMgSi}_{2} \mathrm{O}_{6}(03-0522)$ \\
\hline & & $\mathrm{Ca}_{9} \mathrm{MgK}\left(\mathrm{PO}_{4}\right)_{7}(88-0798)$ \\
\hline \multirow[t]{4}{*}{$2 \mathrm{Zn} 41 \mathrm{Si}$} & 1000 & $\mathrm{Ca} 9 \mathrm{MgK}\left(\mathrm{PO}_{4}\right)_{7}(88-0798)$ \\
\hline & & $\mathrm{Ca}_{9} \mathrm{ZnK}\left(\mathrm{PO}_{4}\right)_{7}(50-0344)$ \\
\hline & & $\mathrm{Mg}_{2} \mathrm{SiO}_{4}(85-1346)$ \\
\hline & & $\mathrm{CaMgSi}_{2} \mathrm{O}_{6}(03-0522)$ \\
\hline \multirow[t]{4}{*}{ 4Zn41Si } & 1000 & $\mathrm{Ca}_{9} \mathrm{MgK}\left(\mathrm{PO}_{4}\right)_{7}(88-0798)$ \\
\hline & & $\mathrm{Ca}_{9} \mathrm{ZnK}\left(\mathrm{PO}_{4}\right)_{7}(50-0344)$ \\
\hline & & $\mathrm{Mg}_{2} \mathrm{SiO}_{4}(85-1346)$ \\
\hline & & $\mathrm{CaMgSi}_{2} \mathrm{O}_{6}(03-0522)$ \\
\hline \multirow[t]{4}{*}{$8 \mathrm{Zn} 41 \mathrm{Si}$} & 980 & $\mathrm{Ca}_{9} \mathrm{MgK}\left(\mathrm{PO}_{4}\right)_{7}(88-0798)$ \\
\hline & & $\mathrm{Ca}_{9} \mathrm{ZnK}\left(\mathrm{PO}_{4}\right)_{7}(50-0344)$ \\
\hline & & $\mathrm{Mg}_{2} \mathrm{SiO}_{4}(85-1346)$ \\
\hline & & $\mathrm{CaMgSi}_{2} \mathrm{O}_{6}(03-0522)$ \\
\hline \multirow[t]{4}{*}{ 15Zn41Si } & 960 & $\mathrm{Ca}_{9} \mathrm{MgK}\left(\mathrm{PO}_{4}\right)_{7}(88-0798)$ \\
\hline & & $\mathrm{Ca}_{9} \mathrm{ZnK}\left(\mathrm{PO}_{4}\right)_{7}(50-0344)$ \\
\hline & & $\mathrm{Mg}_{2} \mathrm{SiO}_{4}(85-1346)$ \\
\hline & & $\mathrm{Zn}_{2} \mathrm{SiO}_{4}(37-1485)$ \\
\hline \multirow[t]{6}{*}{ 30Zn41Si } & 820 & $\mathrm{Ca}_{9} \mathrm{MgK}\left(\mathrm{PO}_{4}\right)_{7}(88-0798)$ \\
\hline & & $\mathrm{Ca}_{9} \mathrm{ZnK}\left(\mathrm{PO}_{4}\right)_{7}(50-0344)$ \\
\hline & & $\mathrm{Zn}_{2} \mathrm{SiO}_{4}(37-1485)$ \\
\hline & 980 & $\mathrm{Ca}_{9} \mathrm{MgK}\left(\mathrm{PO}_{4}\right)_{7}(88-0798)$ \\
\hline & & $\mathrm{Ca}_{9} \mathrm{ZnK}\left(\mathrm{PO}_{4}\right)_{7}(50-0344)$ \\
\hline & & $\mathrm{Zn}_{2} \mathrm{SiO}_{4}(37-1485)$ \\
\hline \multirow[t]{3}{*}{ 0Zn41P } & 660 & $\mathrm{KMg}\left(\mathrm{PO}_{3}\right)_{3}(18-1038)$ \\
\hline & & $\mathrm{CaMgP}_{2} \mathrm{O}_{7}(24-0135)$ \\
\hline & 970 & $\mathrm{CaMgSi}_{2} \mathrm{O}_{6}(03-0522)$ \\
\hline \multirow[t]{3}{*}{ 2Zn41P } & 664 & $\mathrm{KMg}\left(\mathrm{PO}_{3}\right)_{3}(18-1038)$ \\
\hline & & $\mathrm{CaMgP}_{2} \mathrm{O}_{7}(24-0135)$ \\
\hline & & $\mathrm{K}_{2} \mathrm{ZnP}_{2} \mathrm{O}_{7}(34-0442)$ \\
\hline \multirow[t]{3}{*}{ 4Zn41P } & 662 & $\mathrm{KMg}\left(\mathrm{PO}_{3}\right)_{3}(18-1038)$ \\
\hline & & $\mathrm{CaMgP}_{2} \mathrm{O}_{7}(24-0135)$ \\
\hline & & $\mathrm{K}_{2} \mathrm{ZnP}_{2} \mathrm{O}_{7}(34-0442)$ \\
\hline \multirow[t]{3}{*}{ 8Zn41P } & 635 & $\mathrm{KMg}\left(\mathrm{PO}_{3}\right)_{3}(18-1038)$ \\
\hline & & $\mathrm{CaMgP}_{2} \mathrm{O}_{7}(24-0135)$ \\
\hline & & $\mathrm{K}_{2} \mathrm{ZnP}_{2} \mathrm{O}_{7}(34-0442)$ \\
\hline \multirow[t]{3}{*}{$15 Z n 41 P$} & 625 & $\mathrm{KMg}\left(\mathrm{PO}_{3}\right)_{3}(18-1038)$ \\
\hline & & $\mathrm{CaMgP}_{2} \mathrm{O}_{7}(24-0135)$ \\
\hline & & $\mathrm{K}_{2} \mathrm{ZnP}_{2} \mathrm{O}_{7}(34-0442)$ \\
\hline \multirow[t]{3}{*}{$30 \mathrm{Zn} 41 \mathrm{P}$} & 593 & $\mathrm{~K}_{2} \mathrm{ZnP}_{2} \mathrm{O}_{7}(34-0442)$ \\
\hline & & $\mathrm{Mg}_{2} \mathrm{P}_{4} \mathrm{O}_{12}(40-0067)$ \\
\hline & & $\mathrm{CaMgP}_{2} \mathrm{O}_{7}(24-0135)$ \\
\hline
\end{tabular}

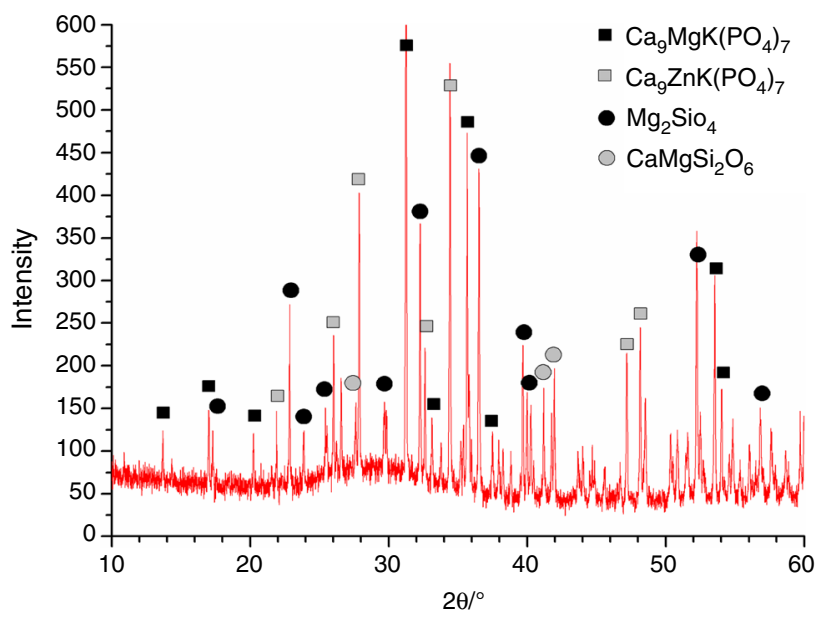

Fig. 4 XRD pattern of the $8 \mathrm{Zn} 41 \mathrm{Si}$ glass after heating at $980{ }^{\circ} \mathrm{C}$

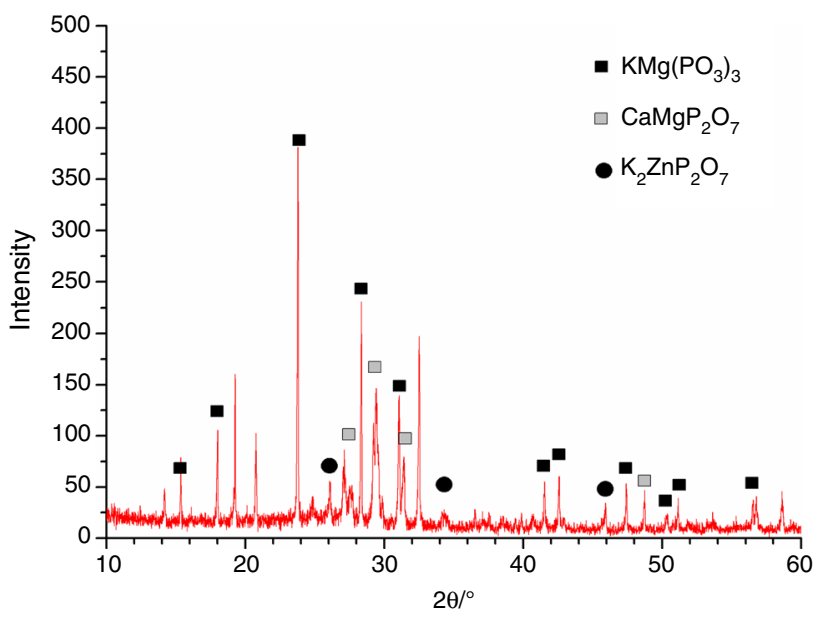

Fig. $5 \mathrm{XRD}$ pattern of the $8 \mathrm{Zn} 41 \mathrm{P}$ glass after heating at $635^{\circ} \mathrm{C}$

Table 4 Values of $\Delta G_{\mathrm{f}}{ }^{\circ}$ of the formation of phosphates and silicates crystallizing in analysed glasses [38]

\begin{tabular}{lccr}
\hline Compounds & \multicolumn{4}{c}{$\Delta G_{\mathrm{f}}{ }^{\circ} / \mathrm{kJ} \mathrm{mol}^{-1}$} & \\
\cline { 2 - 4 } & $900 \mathrm{~K}$ & $1000 \mathrm{~K}$ & $1100 \mathrm{~K}$ \\
\hline $\mathrm{Ca}{ }_{9} \mathrm{MgK}\left(\mathrm{PO}_{4}\right)_{7}$ & $-18,846$ & $-19,196$ & $-19,563$ \\
$\mathrm{Ca}_{9} \mathrm{ZnK}\left(\mathrm{PO}_{4}\right)_{7}$ & $-18,622$ & $-18,842$ & $-19,343$ \\
$\mathrm{Mg}_{2} \mathrm{P}_{4} \mathrm{O}_{12}$ & -8012 & -8093 & -8332 \\
$\left.\mathrm{KMg}_{12} \mathrm{PO}_{3}\right)_{3}$ & -5930 & -5997 & -6182 \\
$\mathrm{CaMgP}_{2} \mathrm{O}_{7}$ & -4695 & -4746 & -4875 \\
$\mathrm{~K}_{2} \mathrm{ZnP}_{2} \mathrm{O}_{7}$ & -4253 & -4316 & -4459 \\
$\mathrm{CaMgSi}_{2} \mathrm{O}_{6}$ & -3271 & -3311 & -3354 \\
$\mathrm{Mg}_{2} \mathrm{SiO}_{4}$ & -2255 & -2282 & -2311 \\
$\mathrm{Zn}_{2} \mathrm{SiO}_{4}$ & -1782 & -1815 & -1846 \\
\hline
\end{tabular}




\section{Conclusions}

Thermal properties of $\mathrm{SiO}_{2}-\mathrm{P}_{2} \mathrm{O}_{5}-\mathrm{K}_{2} \mathrm{O}-\mathrm{CaO}-\mathrm{ZnO}$ glasses with various contents of $\mathrm{SiO}_{2}$, and $\mathrm{P}_{2} \mathrm{O}_{5}$ were investigated. The increased amount of $\mathrm{ZnO}$-replaced $\mathrm{MgO}$ and $\mathrm{CaO}$ in the structure of glasses with both silicate and phosphate matrixes caused decrease in $T_{\mathrm{g}}$ temperature. The lower $T_{\mathrm{g}}$ values observed in the phosphate matrix glasses and the accompanying higher changes in molar heat capacity $\left(\Delta c_{\mathrm{p}}\right)$ in contrast to silicate matrix glasses may be regarded as an indicator of the level of transition of their amorphous structure, which facilitates their crystallization. It was found that the increasing amount of zinc in the structure of both groups of glasses facilitates the formation of complex phosphates containing zinc, which took place during their crystallization. On the other hand, the increasing amount of zinc in the structure of the silicate matrix glasses caused the diversification of crystallization products in the form of silicates containing zinc in contrast to the phosphate matrix glass in which the inhibiting effect of zinc on the crystallization of the silicate phases was observed. The nature of the studied thermal transitions is in accordance with the kinds of bonds in the analysed glasses (crystallochemical factors) and Gibbs free enthalpy of the formation of crystalline compounds (chemical affinity of the glass components).

Acknowledgments The work was supported by Faculty of Materials Science and Ceramics AGH-University of Science and Technology No 11.11.160.617.

Open Access This article is distributed under the terms of the Creative Commons Attribution 4.0 International License (http://crea tivecommons.org/licenses/by/4.0/), which permits unrestricted use, distribution, and reproduction in any medium, provided you give appropriate credit to the original author(s) and the source, provide a link to the Creative Commons license, and indicate if changes were made.

\section{References}

1. Martinez-Martinez R, Speghini A, Bettinelli M, Falcony C, Caldino U. White light generation through the zinc metaphosphate glass activated by $\mathrm{Ce}^{3+}, \mathrm{Tb}^{3+}$ and $\mathrm{Mn}^{2+}$ ions. J Lumin. 2009;129:1276-80.

2. Eriah E, Bhat SG. Optical properties of samarium doped zincphosphate glasses. J Phys Chem Solids. 2007;68:581-5.

3. Fletcher LB, Witcher JJ, Troy N, Reis ST, Brow RK, Krol DM. Effects of rare-earth doping on femtosecond laser waveguide writing in zinc polyphosphate glass. J Appl Phys 2012;112:023109.1-6.

4. Fletcher LB, Witcher JJ, Troy N, Reis ST, Brow RK, Vazques RM, Osellame R, Krol DM. Femtosecond laser writing of waveguides in zinc phosphate glasses. Opt Mater Express. 2011;1:845-55.
5. Fletcher LB, Witcher JJ, Troy N, Reis ST, Brow RK, Krol DM. Direct femtosecond laser waveguide writing inside zinc phosphate glass. Opt Mater Express. 2011;19:7929-36.

6. Canioni L, Bellec M, Royon A, Bousquet B, Cardinal T. Threedimensional optical data storage using third-harmonic generation in silver zinc phosphate glass. Opt Lett. 2008;33:360-2.

7. Wilder JA Jr. Glasses and glass ceramics for sealing to aluminum alloys. J Non-Cryst Solids. 1980;388 \& 339:879-84.

8. Morena RM. Phosphate glasses as alternatives to Pb-based sealing frits. J Non-Cryst Solids. 2000;263 \& 264:382-7.

9. Hall SL, Dimai HP, Farley JR. Effects of zinc on human skeletal alkaline phosphatase activity in vitro. Calcif Tissue Int. 1999;64:163-72.

10. Wu X, Itoh N, Taniguchi T, Nakanishi T, Tatsu Y, Yumoto N, Tanaka K. Zinc-induced sodium-dependent vitamin $\mathrm{C}$ transporter 2 expression: potent roles in osteoblast differentiation. Arch Biochem Biophys. 2003;420:114-20.

11. Ramswamy $\mathrm{Y}, \mathrm{Wu} \mathrm{C}$, Zhou $\mathrm{H}$, Zreiquat $\mathrm{H}$. Biological response of human bone cells to zinc-modified $\mathrm{Ca}-\mathrm{Si}$ based ceramics. Acta Biomater. 2008;3:1487-97.

12. Ito A, Ojima K, Natio H, Ichinose N, Tateischi T. Preparation, solubility and cytompatibility of zinc-releasing calcium phosphate ceramics. J Biomed Mater Res. 2000;50:178-83.

13. Salih V, Patel A, Knowles JC. Zinc-containing phosphate-based glasses for tissue engineering. Biomed Mater. 2007;2:11-20.

14. Osinaga PW, Grande RH, Ballester RY, Simionato MR, Delgado Rodrigues CR, Muench A. Zinc sulfate addition to glass-ionomer-based cements: influence on physical and antibacterial properties, zinc and fluoride release. Dent Mater. 2003;19:212-7.

15. Bright KR, Gerba CP, Rusin PA. Rapid reduction of Staphylococcus aureus populations on stainless steel surfaces by zeolite ceramic coatings containing silver and zinc ions. J Hosp Infect. 2002;52:307-9.

16. Szumera M, Wacławska I. Effect of molybdenum addition on the thermal properties of silicate-phosphate glasses. J Therm Anal Cal. 2012;109:649-55.

17. Sułowska J, Wacławska I, Szumera M. Effect of copper addition on glass transition of silicate-phosphate glasses. J Therm Anal Cal. 2012;109:705-10.

18. Takebe H, Baba Y, Kuwabara M. Dissolution behavior of $\mathrm{ZnO}$ $\mathrm{P}_{2} \mathrm{O}_{5}$ glasses in water. J Non-Cryst Solids. 2006;352:3088-94.

19. Wiench J, Pruski M, Tischendorf B, Otaigbe J, Sales B. Structural studies of zinc polyphosphate glasses by nuclear magnetic resonance. J Non-Cryst Solids. 2000;263-264:101-10.

20. Tischendorf B, Otaigbe J, Wiench J, Pruski M, Sales B. A study of short and intermediate range order in zinc phosphate glasses. J Non-Cryst Solids. 2001;282:147-58.

21. Kaur G, Sharma P, Kumar V, Singh K. Assessment of in vitro bioactivity of $\mathrm{SiO}_{2}-\mathrm{BaO}-\mathrm{ZnO}-\mathrm{B}_{2} \mathrm{O}_{3}-\mathrm{Al}_{2} \mathrm{O}_{3}$ glasses: an opticoanalytical approach. Mater Sci Eng, C. 2012;32:1941-7.

22. Hurt J, Philips C. Structural role of zinc oxide in glasses in the system $\mathrm{Na}_{2} \mathrm{O}-\mathrm{ZnO}-\mathrm{SiO}_{2}$. J Am Ceram Sci. 1970;53:269-73.

23. Minser D, Walden B, White W. Structure of alkali-zinc silicate glasses by Raman Spectroscopy. Commun Am Ceram Sci. 1984:C-47.

24. Chen X, Brauer D, Karpukhina N, Waite R, Barry M, McKay I, Hill R. 'Smart' acid-degradable zinc-releasing silicate glasses. Mater Lett. 2014;126:278-80.

25. Goel A, Kappor S, Tilocca A, Rajagopal R, Ferreira M. Structural role of zinc in biodegradation of alkali-free bioactive glasses. J Mater Chem B. 2013;1:3073-82.

26. Aina V, Malavasi G, Fiorio Pla A, Munaron L, Morterra C. Zinccontaining bioactive glasses: surface reactivity and behaviour towards endothelial cells. Acta Biomater. 2009;5:1211-22. 
27. Demirkesen E, Maytalman E. Effect of $\mathrm{Al}_{2} \mathrm{O}_{3}$ additions on the crystallization behaviour and bending strength of $\mathrm{Li}_{2} \mathrm{O}-\mathrm{ZnO}-$ $\mathrm{SiO}_{2}$ glasses. J Non-Cryst Solids. 2001;27:287-93.

28. Abou Neel EA, O’Dell LA, Smith ME, Knowles JC. Processing, characterisation, and biocompatibility of zinc modified metaphosphate based glasses for biomedical applications. J Mater Sci Mater Med. 2008;19:1669-79.

29. Pascuta P, Bosca M, Borodi G, Culea E. Thermal, structural and magnetic properties of some zinc phosphate glasses doped with manganese ions. J Alloy Compd. 2011;509:4314-9.

30. Smith CE, Brow RK. The properties and structure of zinc magnesium phosphate glasses. J Non-Cryst Solids. 2014;390:51-8.

31. Demirkesen E, Maytalman E. Effect of $\mathrm{Al}_{2} \mathrm{O}_{3}$ additions on the crystallization behavior and bending strength of a $\mathrm{Li}_{2} \mathrm{O}-\mathrm{ZnO}-$ $\mathrm{SiO}_{2}$ glass-ceramic. Ceram Int. 2001;27:99-104.
32. Wers E, Oudadesse H. Thermal behavior and excess entropy of bioactive glasses and $\mathrm{Zn}$-doped glasses. J Therm Anal Cal. 2014; 115:2137-44.

33. Stoch L, Stoch Z, Wacławska I. Silicate glass fertilizer. Patent PL 185229 B1. 2003 [Polish].

34. Kabata Pendias A, Pendias H. Biogeochemistry of trace elements. Warsaw: Polish Scientific Publishers (PWN); 1993 (in Polish).

35. Görlich E. The effective charges and the electronegativity. Krakow: Polish Academy of Art and Science; 1997.

36. Stoch L. Thermal analysis and thermochemistry of vitreous into crystalline state transition. J Therm Anal Cal. 2004;77:7-16.

37. Brow RK, Click CA, Alam TM. Modifier coordination and phosphate glass networks. J Non-Cryst Solids. 2000;274:9-16.

38. Barin I, Knacke O. Thermochemical properties of inorganic substances. Berlin: Springer; 1973. 